Article

\title{
Peniginsengins B-E, New Farnesylcyclohexenones from the Deep Sea-Derived Fungus Penicillium sp. YPGA11
}

\author{
Zhongbin Cheng ${ }^{1,4,+}$, Wei Xu ${ }^{2,+}$, Lijun Liu ${ }^{1}$, Shumin $\mathrm{Li}^{1}$, Wangjun Yuan ${ }^{1,3}$, Zhuhua Luo ${ }^{3}$, \\ Jingjie Zhang ${ }^{1}$, Yongjun Cheng ${ }^{1}$ and Qin $\mathrm{Li}^{1}{ }^{1,3, *}$ \\ 1 College of Pharmacy, Henan University, Kaifeng 475004, China; czb360@126.com (Z.C.); \\ 15736871748@163.com (L.L.); lishumin417@163.com (S.L.); yuanwangjun@henu.edu.cn (W.Y.); \\ zhang521571@163.com (J.Z.); chyj15926@163.com (Y.C.) \\ 2 Key Laboratory of Marine Biogenetic Resources, Third Institute of Oceanography, \\ State Oceanic Administration, Xiamen 361005, China; xuwei@tio.org.cn (W.X.); luozhuhua@tio.org.cn (Z.L.) \\ 3 Eucommia Ulmoides Cultivation and Utilization of Henan Engineering Laboratory, Kaifeng 475004, China \\ 4 College of Chemistry and Chemical Engineering, Henan University, Kaifeng 475004, China \\ * Correspondence: liqin6006@163.com; Tel.: +86-371-2388-3849 \\ + These authors contributed equally to this work.
}

Received: 6 September 2018; Accepted: 27 September 2018; Published: 1 October 2018

\begin{abstract}
Chemical examination of the EtOAc extract of the deep sea-derived fungus Penicillium sp. YPGA11 resulted in the isolation of four new farnesylcyclohexenones, peniginsengins B-E (1-4), and a known analog peniginsengin A (5). The structures of compounds 1-4 were determined on the basis of comprehensive analyses of the nuclear magnetic resonance (NMR) and mass spectroscopy (MS) data, and the absolute configurations of $\mathbf{1}, \mathbf{2}$, and $\mathbf{4}$ were determined by comparisons of experimental electronic circular dichroism (ECD) with calculated ECD spectra. Compounds 1-5, characterized by a highly oxygenated 1-methylcyclohexene unit and a (4E,8E)-4,8-dimethyldeca-4,8-dienoic acid side chain, are rarely found in nature. Compounds $\mathbf{2}-\mathbf{4}$ exhibited antibacterial activity against Staphylococcus aureus.
\end{abstract}

Keywords: Penicillium sp.; deep sea-derived fungus; farnesylcyclohexenones; antibacterial

\section{Introduction}

The genus Penicillium is widely distributed in all environments, and has become one of the most well-known genera of fungi for the discovery of bioactive compounds [1]. To date, Penicillium species have provided us with several major clinical drugs, such as the well-known antibacterial penicillin and the remarkable lipid-lowering agent mevastatin. In recent years, marine-derived Penicillium have drawn attention of natural prodcuct chemists and have been increasingly investigated, leading to the discovery of thousands of secondary metabolites, some of which are structurally unique or biologically significant [2-9]. For example, simpterpenoid A, an unprecedented meroterpenoid isolated from mangrove-derived Penicillium simplicissimum, exhibited inhibitory activity against influenza neuraminidase with an $\mathrm{IC}_{50}$ value of $8.1 \mathrm{nM}$ [4].

As part of our ongoing efforts to discover bioactive molecules from marine-derived fungi [10-13], a EtOAc extract of the fungal fermentation of the deep-sea-derived fungus Penicillium sp. YPGA11 possessed inhibitory effects against Staphylococcus aureus ATCC 25913 at a single dose $(100 \mu \mathrm{g} / \mathrm{mL})$. Further chromatographic separation of the extract yielded the known farnesylcyclohexenone peniginsengin A (5) [14], and four new analogs 1-4 (Figure 1). Compounds 1-4, containing a highly oxygenated 1-methylcyclohexene unit and a rare $(4 E, 8 E)-4,8$-dimethyldeca-4,8-dienoic acid side chain, 
are rarely found in nature $[14,15]$. The absolute configurations of this class of compounds were resolved for the first time by electronic circular dichroism (ECD) calculations in the current study. Compounds 1-4 were screened for their inhibitory effects against Staphylococcus aureus ATCC 25913 (methicillin-sensitive S. aureus, MSSA) and Staphylococcus aureus ATCC43300 (methicillin-resistant S. aureus, MRSA). Herein, the details of the isolation, structure elucidation, and antibacterial activity of 1-4 are described.
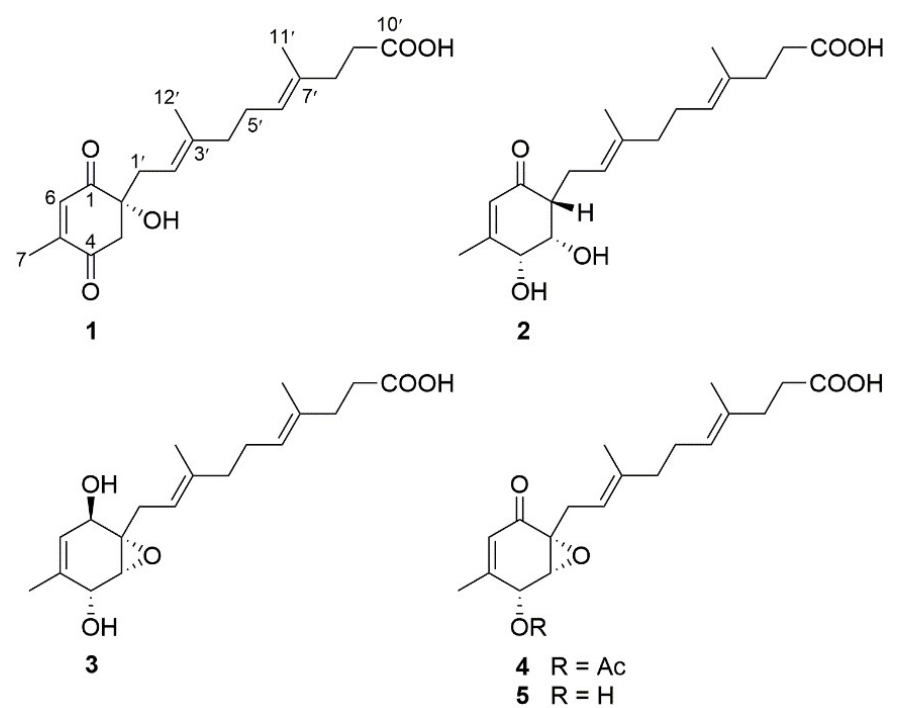

Figure 1. Structures of compounds 1-5 from Penicillium sp.

\section{Results and Discussion}

Peniginsengin $\mathrm{B}(\mathbf{1})$ had a molecular formula $\mathrm{C}_{19} \mathrm{H}_{26} \mathrm{O}_{5}$, as established by high-resolution electrospray ionization mass spectroscopy (HRESIMS) (333.1703 [M - H] ${ }^{-}$) and nuclear magnetic resonance (NMR) data (Supplementary Materials Figure S25 and Table 1), indicating seven degrees of unsaturation. The ${ }^{1} \mathrm{H}$ NMR and heteronuclear single quantum coherence (HSQC) spectra provided the signals for three olefinic methyl groups $\left(\delta_{\mathrm{H}} 1.89,1.55,1.48\right)$, three olefinic protons $\left(\delta_{\mathrm{H}} 6.69,5.02,5.06\right)$, and a series of alkyl protons, while the ${ }^{13} \mathrm{C}$ NMR spectrum exhibited a total of 19 carbon resonances, including six olefinic carbons for three double bonds $\left(\delta_{C} 135.7,150.3,118.4,138.1,123.9\right.$, and 133.7), three carbonyl carbons for two ketones $\left(\delta_{C} 197.1\right.$ and 199.6) and a carboxylic group $\left(\delta_{C} 174.2\right)$, and an oxyquaternary carbon $\left(\delta_{C} 77.1\right)$. As six of the seven degrees of unsaturation were accounted for by three double bonds and three carbonyl carbons, the remaining degree of unsaturation required that 1 was monocyclic.

The aforementioned information was quite similar to that of the co-isolated compound, peniginsengin A (5) [14]. Comparison of their NMR data indicated that they shared the same side chain and the differences were attributed to the substitutions of the cyclohexenone moiety, which was established by heteronuclear multiple bond correlations (HMBC) (Figure 2). The HMBC correlations from the easily recognizable $\mathrm{CH}_{3}-7\left(\delta_{\mathrm{H}} 1.89\right)$ signal to $C-4\left(\delta_{C} 197.1\right), \mathrm{C}-5\left(\delta_{\mathrm{C}} 150.3\right)$, and C-6 $\left(\delta_{\mathrm{C}} 135.7\right)$ assigned an $\alpha, \beta$-unsaturated ketone residing at C-4, C-5, and C-6 (Figure 2). Additional HMBC correlations from $\mathrm{H}-6\left(\delta_{\mathrm{H}} 6.69\right)$ to the oxyquaternary carbon $\mathrm{C}-2\left(\delta_{\mathrm{C}} 77.1\right)$ and C-4 and from the methylene protons $\mathrm{H}_{2}-3\left(\delta_{\mathrm{H}} 2.87,2.80\right)$ to $\mathrm{C}-1$ ( $\left.\delta_{\mathrm{C}} 199.6\right), \mathrm{C}-2, \mathrm{C}-4$, and $\mathrm{C}-5$ led to the establishment of the cyclohexendione moiety. The structure of the side chain, containing two isoprene and one acetic acid fragments, was secured by analyses of correlation spectroscopy (COSY) and HMBC correlations (Figure 2). The side chain was connected to $\mathrm{C}-2$ by HMBC correlations from $\mathrm{H}_{2}-1^{\prime}\left(\delta_{\mathrm{H}} 2.35,2.22\right)$ to $\mathrm{C}-1$ and C-2. 
Table 1. ${ }^{1} \mathrm{H}$ and ${ }^{13} \mathrm{C}$ nuclear magnetic resonance (NMR) data of $\mathbf{1}$ and $\mathbf{2}\left(\mathbf{1}\right.$ in DMSO- $d_{6}$ and $\mathbf{2}$ in $\mathrm{CD}_{3} \mathrm{OD}$, $\delta$ in ppm).

\begin{tabular}{|c|c|c|c|c|}
\hline \multirow{2}{*}{ No. } & \multicolumn{2}{|c|}{1} & \multicolumn{2}{|l|}{2} \\
\hline & $\delta_{\mathrm{H}}{ }^{a}($ Mult, $J$ in $\mathrm{Hz})$ & $\delta_{C}^{b}$, Type & $\delta_{H}{ }^{c}($ Mult, $J$ in $\mathrm{Hz})$ & $\delta_{C}{ }^{d}$, Type \\
\hline 1 & & 199.6, C & & 201.4, C \\
\hline 2 & & 77.1, C & 2.43 , ddd $(10.2,3.8,2.3)$ & $53.4, \mathrm{CH}$ \\
\hline 3 & $\begin{array}{l}2.87, \mathrm{~d}(15.9) \\
2.80, \mathrm{~d}(15.9)\end{array}$ & $49.5, \mathrm{CH}_{2}$ & $4.20, \mathrm{dd}(3.0,2.3)$ & 73.7, $\mathrm{CH}$ \\
\hline 4 & & 197.1, C & $4.44, \mathrm{br} \mathrm{s}$ & $73.3, \mathrm{CH}$ \\
\hline 5 & & $150.3, \mathrm{C}$ & & $162.4, \mathrm{C}$ \\
\hline 6 & $6.69, \mathrm{~d}(1.34)$ & 135.7, $\mathrm{CH}$ & 5.84, br s & $126.8, \mathrm{CH}$ \\
\hline 7 & $1.89, \mathrm{~d}(1.34)$ & $15.5, \mathrm{CH}_{3}$ & $2.02, \mathrm{br} \mathrm{s}$ & $20.3, \mathrm{CH}_{3}$ \\
\hline $1^{\prime}$ & $\begin{array}{l}2.35, \mathrm{dd}(14.0,7.4) \\
2.22, \mathrm{dd}(14.0,7.4)\end{array}$ & $36.8, \mathrm{CH}_{2}$ & $\begin{array}{c}2.25, \mathrm{~m} \\
2.60, \text { ddd }(14.5,6.9,3.8)\end{array}$ & 24.4, $\mathrm{CH}_{2}$ \\
\hline $2^{\prime}$ & $5.02, \mathrm{t}(7.4)$ & $118.4, \mathrm{CH}$ & $5.17, \mathrm{t}(6.9)$ & $123.2, \mathrm{CH}$ \\
\hline $3^{\prime}$ & & 138.1, C & & 138.1, C \\
\hline $4^{\prime}$ & $1.93, \mathrm{~m}$ & $39.5, \mathrm{CH}_{2}$ & $2.05, \mathrm{~m}$ & $40.7, \mathrm{CH}_{2}$ \\
\hline $5^{\prime}$ & $1.99, \mathrm{~m}$ & $25.8, \mathrm{CH}_{2}$ & $2.13, \mathrm{~m}$ & $27.5, \mathrm{CH}_{2}$ \\
\hline $6^{\prime}$ & $5.06, \mathrm{t}(6.60)$ & $123.9, \mathrm{CH}$ & $5.16, \mathrm{t}(5.9)$ & $125.9, \mathrm{CH}$ \\
\hline $7^{\prime}$ & & $133.7 \mathrm{C}$ & & 134.7, C \\
\hline $8^{\prime}$ & $2.15, \mathrm{~m}$ & $34.2, \mathrm{CH}_{2}$ & $2.27, \mathrm{~m}$ & $35.7, \mathrm{CH}_{2}$ \\
\hline $9^{\prime}$ & $2.24, \mathrm{~m}$ & $32.7, \mathrm{CH}_{2}$ & $2.38, \mathrm{~m}$ & $34.0, \mathrm{CH}_{2}$ \\
\hline $10^{\prime}$ & & $174.2, \mathrm{C}$ & & $177.4, \mathrm{C}$ \\
\hline $11^{\prime}$ & $1.55, \mathrm{~s}$ & $15.8, \mathrm{CH}_{3}$ & $1.63, \mathrm{~s}$ & $16.1, \mathrm{CH}_{3}$ \\
\hline $12^{\prime}$ & $1.48, \mathrm{~s}$ & $16.0, \mathrm{CH}_{3}$ & $1.66, \mathrm{~s}$ & $16.2, \mathrm{CH}_{3}$ \\
\hline
\end{tabular}

${ }^{\text {a }}$ Recorded at $400 \mathrm{MHz},{ }^{\mathrm{b}}$ Recorded at $100 \mathrm{MHz},{ }^{\mathrm{c}}$ Recorded at $600 \mathrm{MHz},{ }^{\mathrm{d}}$ Recorded at $150 \mathrm{MHz}$.
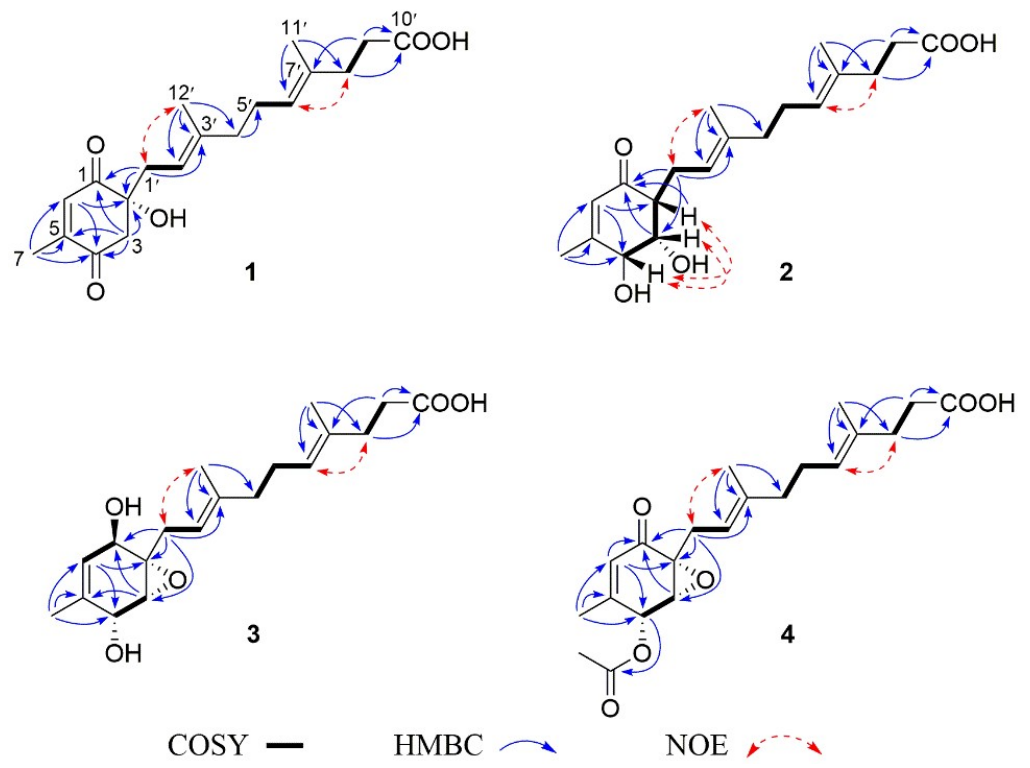

NOE

Figure 2. Key correlation spectroscopy (COSY), heteronuclear multiple bond correlation (HMBC), and nuclear Overhauser effect (NOE) correlations of 1-4. 
The configurations of $\Delta^{2^{\prime}}$ and $\Delta^{6^{\prime}}$ were both assigned as $E$ by the NOE correlations of $\mathrm{H}_{2}-1^{\prime} / \mathrm{H}_{3}-12^{\prime}$ $\left(\delta_{\mathrm{H}} 1.48, \mathrm{~s}\right)$ and $\mathrm{H}-6^{\prime}\left(\delta_{\mathrm{H}} 5.06\right) / \mathrm{H}_{2}-8^{\prime}\left(\delta_{\mathrm{H}} 2.15\right)$ (Figure 2). The absolute configuration of the only chiral center of C-2 in 1 was resolved by comparing its experimental ECD spectrum with the calculated ECD spectra for the (2S/2R)-1 using the time-dependent density functional theory (TDDFT) computational method (Figure 3). The experimental ECD spectrum of 1 showed an ECD curve with Cotton effects around $241(-)$ and $226(+) \mathrm{nm}$, respectively. The calculated ECD spectrum for (2R)-1 showed a similar ECD curve with Cotton effects at $242(-)$ and $227(+) \mathrm{nm}$, which allowed the assignment of the absolute configuration of $\mathrm{C}-2$ to be $R$.

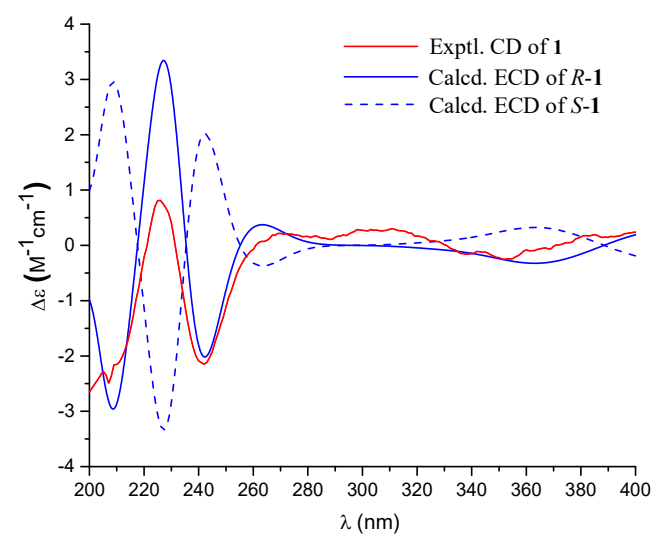

Figure 3. Experimental and calculated electronic circular dichroism (ECD) spectra of $\mathbf{1}$.

The molecular formula of 2 was determined as $\mathrm{C}_{19} \mathrm{H}_{28} \mathrm{O}_{5}$ by the HRESIMS data $(\mathrm{m} / \mathrm{z}$ $335.1862[\mathrm{M}-\mathrm{H}]^{-}$), indicating six degrees of unsaturation. The ${ }^{1} \mathrm{H}$ NMR and ${ }^{13} \mathrm{C}$ NMR data (Supplementary Materials Figure S26 and Table 1) showed signals for an $\alpha, \beta$-methyl-unsaturated ketone $\left(\delta_{\mathrm{H}} 5.84,2.02 ; \delta_{\mathrm{C}} 201.4,126.8,162.4,20.3\right)$, a methine $\left(\delta_{\mathrm{H}} 2.43 ; \delta_{\mathrm{C}} 53.4\right)$, two oxymethines $\left(\delta_{\mathrm{H}} 4.44,4.20 ; \delta_{\mathrm{C}} 73.3,73.7\right)$, and an identical side chain as that of 5 . These data showed high similarity to those of 5 with obvious differences owing to two downfield-shifted oxymethines $\left(\delta_{C} 73.3\right.$ and 73.7 in $2 ; \delta_{C} 68.0$ and 59.4 in 5$)$ and the presence of one more methine $\left(\delta_{C} 53.4\right)$ in 2 instead of the oxyquaternary carbon $\left(\delta_{C} 61.9\right)$ in 5 , suggesting that 2 was the epoxy-hydrogenated derivative of 5 . The HMBC correlations from H-6 $\left(\delta_{\mathrm{H}} 5.84\right)$ and $\mathrm{H}_{3}-7\left(\delta_{\mathrm{H}} 2.02\right)$ to $\mathrm{C}-4\left(\delta_{\mathrm{C}} 73.3\right), \mathrm{H}-6$ to $\mathrm{C}-2\left(\delta_{\mathrm{C}} 53.4\right)$, and COSY correlations from $\mathrm{H}-2\left(\delta_{\mathrm{H}} 2.43\right)$ to $\mathrm{H}-4\left(\delta_{\mathrm{H}} 4.44\right)$ confirmed the deduction and clearly clarified the structure of the cyclohexenone moiety (Figure 2). The side chain determined by 2D NMR data (Figure 2) was linked to the cyclohexenone moiety at C-2 by HMBC correlations from $\mathrm{H}_{2}-1^{\prime}\left(\delta_{\mathrm{H}} 2.25,2.60\right)$ to $\mathrm{C}-1\left(\delta_{\mathrm{C}} 201.4\right)$ and $\mathrm{C}-3\left(\delta_{\mathrm{C}} 73.7\right)$ combining with the COSY correlations of $\mathrm{H}-2$ with $\mathrm{H}_{2}-1^{\prime}$. Thus, the gross structure of 2 was deduced as shown in Figure 1.

The relative configuration of 2 was determined by nuclear Overhauser effect spectroscopy (NOESY) data (Figure 2) and $J$ values. The NOE correlations between $\mathrm{H}-2$ and $\mathrm{H}-4$ determined that they were in the same orientation. The coupling constant $J_{\mathrm{H}-3 / \mathrm{H}-4}(3.0 \mathrm{~Hz})$ was indicative of the cis-relationship of H-3 and $\mathrm{H}-4$ [6], which agreed with the NOE correlation between $\mathrm{H}-3$ and $\mathrm{H}-4$. Therefore, the relative configuration of 2 was assigned as $2 R^{*}, 3 S,{ }^{*}$ and $4 R^{*}$. Comparison of the experimental ECD spectra with those of the calculated ECD data for the model molecule with the $2 R$, $3 S$, and $4 R$ configuration and its enantiomer allowed the assignment of the $2 R, 3 S$, and $4 R$ configurations for 2 (Figure 4). 


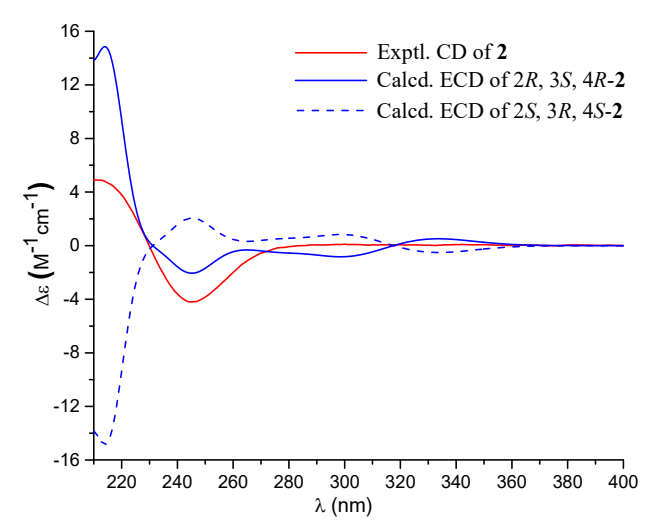

Figure 4. Experimental and calculated ECD spectra of 2.

Compound 3 had a molecular formula of $\mathrm{C}_{19} \mathrm{H}_{28} \mathrm{O}_{5}$ as determined by the HRESIMS $(\mathrm{m} / \mathrm{z}$ $335.1868[\mathrm{M}-\mathrm{H}]^{-}$) and NMR data (Supplementary Materials Figure S27 and Table 2). Comparison of the NMR data revealed the structure of 3 to be closely related to 5 . The difference was found by the presence of an additional oxymethine $\left(\delta_{C} 67.2\right)$ in 3 instead of the ketone group $\left(\delta_{C} 194.0\right)$ in 5 , indicating 3 was the carbonyl-hydrogenated derivative of 5 . This deduction was evident from the COSY relationship between $\mathrm{H}-1\left(\delta_{\mathrm{H}} 4.18\right)$ and $\mathrm{H}-6\left(\delta_{\mathrm{H}} 5.23\right)$ in addition to the HMBC correlations from $\mathrm{H}-3\left(\delta_{\mathrm{H}} 3.31\right)$ and $\mathrm{H}-1^{\prime}\left(\delta_{\mathrm{H}} 2.90\right.$ and 2.12) to $\mathrm{C}-1\left(\delta_{\mathrm{C}} 67.2\right)$ (Figure 2). The coupling constant $J_{\mathrm{H}-3 / \mathrm{H}-4}\left(2.3 \mathrm{~Hz}\right.$, in DMSO- $d_{6}$, see Table S1) suggested a cis relationship between H-3 and H-4 and were assigned as $\alpha$-oriented [16]. The OH- 1 was determined to be $\beta$ oriented by the absence of NOE correlation between $\mathrm{H}-3$ and H-1 and was supported by comparison of the NMR data with those of craterellin D [17], a merosesquiterpenoid isolated from the soft coral-derived fungus Lophiostoma sp. Thus, the gross structure of $\mathbf{3}$ was established as shown in Figure 1. The absolute configuration of the stereogenic centers in 3 was proposed to be $1 R, 2 S, 3 R$, and $4 R$ based on biogenetic consideration and by comparing its specific rotation with those of $\mathbf{1}$ and 2 .

Compound 4 had a molecular formula of $\mathrm{C}_{21} \mathrm{H}_{28} \mathrm{O}_{6}$ as determined by the HRESIMS $(\mathrm{m} / \mathrm{z}$ $\left.375.1813[\mathrm{M}-\mathrm{H}]^{-}\right)$. A comparison of their NMR data revealed the structure of 4 closely related to 5 with the distinction by presence of an acetyl group $\left(\delta_{H} 2.20 ; \delta_{C} 20.6,171.9\right)$. The location of the acetyl group at C-4 was assigned by the HMBC correlation from $\mathrm{H}-4\left(\delta_{\mathrm{H}} 5.85\right)$ to the acetyl carbonyl carbon $\left(\delta_{C} 171.9\right)$ in association with the COSY correlations between $\mathrm{H}-3\left(\delta_{\mathrm{H}} 3.70\right)$ and $\mathrm{H}-4$ (Figure 2$)$. The similar NOE correlations and $J$ values of 4 and 5 confirmed both compounds possessing the same relative configuration. Thus, 4 was the acetyl derivative of 5 .

In the literature, the absolute configuration of 5 was left resolved. The ECD spectra of the model molecule with the $2 R, 3 R$, and $4 R$ configuration and its enantiomer were calculated (Figure 5 ), Comparison of the experimental ECD data of 5 with the calculated data for the model molecules indicated 5 to be in agreement with the $2 R, 3 R$, and $4 R$ configurations. In addition, the similar Cotton effects of $\mathbf{4}$ and $\mathbf{5}$ in the ECD spectra assigned $\mathbf{4}$ with the same absolute configuration as $\mathbf{5}$ (Figure 5). 
Table 2. ${ }^{1} \mathrm{H}$ and ${ }^{13} \mathrm{C}$ NMR data of 3 and $4\left(\mathrm{CD}_{3} \mathrm{OD}, \delta\right.$ in $\left.\mathrm{ppm}\right)$.

\begin{tabular}{|c|c|c|c|c|}
\hline \multirow{2}{*}{ No. } & \multicolumn{2}{|c|}{3} & \multicolumn{2}{|c|}{4} \\
\hline & $\delta_{\mathrm{H}}{ }^{a}($ Mult, $J$ in $\mathrm{Hz})$ & $\delta_{C}{ }^{b}$, Type & $\delta_{H}{ }^{a}($ Mult, $J$ in $\mathrm{Hz})$ & $\delta_{C}{ }^{b}$, Type \\
\hline 1 & $4.18, \mathrm{~m}$ & $67.2, \mathrm{CH}$ & & $194.9, \mathrm{C}$ \\
\hline 2 & & $63.8, \mathrm{C}$ & & $61.3, \mathrm{C}$ \\
\hline 3 & $3.31, \mathrm{~m}$ & $61.4, \mathrm{CH}$ & $3.70, \mathrm{~d}(2.6)$ & $57.5, \mathrm{CH}$ \\
\hline 4 & $4.19, \mathrm{~m}$ & $68.3, \mathrm{CH}$ & $5.85, \mathrm{~d}(2.6)$ & $70.3, \mathrm{CH}$ \\
\hline 5 & & $134.9, \mathrm{C}$ & & $154.5, \mathrm{C}$ \\
\hline 6 & $5.23, \mathrm{~m}$ & $124.9, \mathrm{CH}$ & 5.83, br s & $125.4, \mathrm{CH}$ \\
\hline 7 & $1.75, \mathrm{~s}$ & $19.2, \mathrm{CH}_{3}$ & 1.89, br s & $19.8, \mathrm{CH}_{3}$ \\
\hline $1^{\prime}$ & $\begin{array}{l}2.90, \mathrm{~d}(14.6,8.9) \\
2.12 \text {, d }(14.6,8.9)\end{array}$ & $32.1, \mathrm{CH}_{2}$ & $\begin{array}{l}2.74, \text { dd }(15.2,7.9) \\
2.44, \text { dd }(15.2,6.8)\end{array}$ & 27.0, $\mathrm{CH}_{2}$ \\
\hline $2^{\prime}$ & $5.14, \mathrm{~m}$ & $119.6, \mathrm{CH}$ & $5.03, \mathrm{dd}(7.9,6.8)$ & $118.0, \mathrm{CH}$ \\
\hline $3^{\prime}$ & & $139.8 \mathrm{C}$ & & $140.4, \mathrm{C}$ \\
\hline $4^{\prime}$ & $2.06, \mathrm{~m}$ & $40.7, \mathrm{CH}_{2}$ & $2.02, \mathrm{~m}$ & $40.6, \mathrm{CH}_{2}$ \\
\hline $5^{\prime}$ & $2.13, \mathrm{~m}$ & $27.2, \mathrm{CH}_{2}$ & $2.09, \mathrm{~m}$ & $27.2, \mathrm{CH}_{2}$ \\
\hline $6^{\prime}$ & $5.13, \mathrm{~m}$ & 125.7, $\mathrm{CH}$ & $5.12, \mathrm{dd}(7.7,6.9)$ & $125.6, \mathrm{CH}$ \\
\hline $7^{\prime}$ & & 135.0, C & & $135.1, \mathrm{C}$ \\
\hline $8^{\prime}$ & $2.25, \mathrm{t}(7.7)$ & $35.9, \mathrm{CH}_{2}$ & $2.25, \mathrm{~m}$ & $36.0, \mathrm{CH}_{2}$ \\
\hline $9^{\prime}$ & $2.35, \mathrm{t}(7.7)$ & $34.3, \mathrm{CH}_{2}$ & $2.35, \mathrm{~m}$ & $34.5, \mathrm{CH}_{2}$ \\
\hline $10^{\prime}$ & & 177.7, C & & $177.8, \mathrm{C}$ \\
\hline $11^{\prime}$ & $1.67, \mathrm{~s}$ & $16.4, \mathrm{CH}_{3}$ & $1.64, \mathrm{~s}$ & $16.4, \mathrm{CH}_{3}$ \\
\hline $12^{\prime}$ & $1.62, \mathrm{~s}$ & $16.1, \mathrm{CH}_{3}$ & $1.62, \mathrm{~s}$ & $16.1, \mathrm{CH}_{3}$ \\
\hline 1-OAc & & & $2.20, \mathrm{~s}$ & $\begin{array}{c}20.6, \mathrm{CH}_{3} \\
171.9, \mathrm{C}\end{array}$ \\
\hline
\end{tabular}

${ }^{\mathrm{a}}{ }^{1} \mathrm{H}$ NMR recorded at $600 \mathrm{MHz},{ }^{\mathrm{b}}{ }^{13} \mathrm{C}$ NMR recorded at $150 \mathrm{MHz}$.

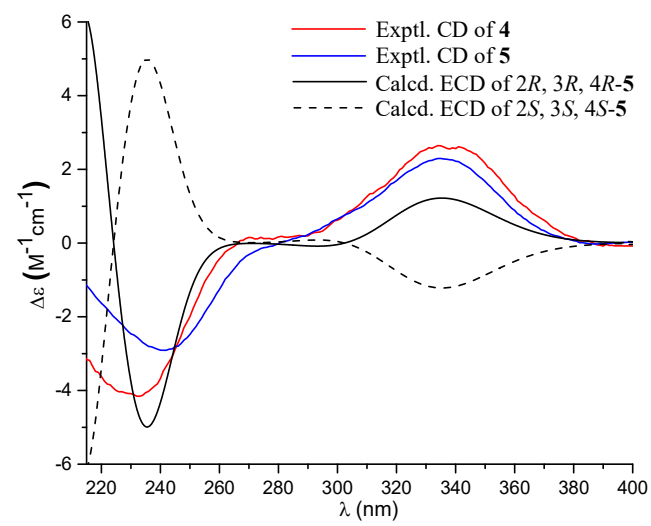

Figure 5. Experimental and calculated ECD spectra of 4 and 5.

Compounds 1-4 were tested for their antibacterial activity against S. aureus ATCC 25913 and S. aureus ATCC 43300. The results (Table 3) revealed that $\mathbf{2}-\mathbf{4}$ possessed moderate activity against S. aureus ATCC 25913 with MIC values from 8 to $32 \mathrm{ug} / \mathrm{mL}$. Compounds 2 and 4 exhibited inhibitory effect against S. aureus ATCC 43300 with MIC values of 32 and $64 \mathrm{ug} / \mathrm{mL}$, respectively. 
Table 3. Antibacterial activity of $\mathbf{1 - 4}$.

\begin{tabular}{ccc}
\hline \multirow{2}{*}{ No. } & \multicolumn{2}{c}{ MIC $(\mu \mathrm{g} / \mathrm{mL})$} \\
\cline { 2 - 3 } & S. aureus ATCC 25913 & S. aureus ATCC 43300 \\
\hline $\mathbf{1}$ & $>128$ & $>128$ \\
$\mathbf{2}$ & 8 & 32 \\
$\mathbf{3}$ & 16 & $>128$ \\
$\mathbf{4}$ & 32 & 64 \\
Penicillin $^{\text {a }}$ & $<0.5$ & $>128$ \\
Vancomycin $^{\text {a }}$ & $-{ }^{\mathrm{b}}$ & $<0.5$ \\
\hline \multicolumn{3}{c}{}
\end{tabular}

Natural products featuring a highly oxygenated 1-methylcyclohexene unit connected with an isoprene-derived carboxylic acid side chain are rarely found in nature. Most cases belong to the well-known bioactive ambuic acid derivatives [18-22], which comprises the same conservative E-2-methylbut-2-enoic acid (5-carbon) side chain. The antibacterial polyketides penicyclones $\mathrm{D}$ and $\mathrm{E}$, isolated from deep-sea-derived Penicillium sp., contain rare isoprene-derived 7-carbon side chains [6]. Peniginsengins A-E, bearing similar 1-methylcyclohexene moiety as those of ambuic acid derivatives and penicyclones, possess a distinctive (4E,8E)-4,8-dimethyldeca-4,8-dienoic acid (12-carbon) side chain and are rarely found in nature. Biogenetically, peniginsengins might derive from farnesylcyclohexene via oxidative cleavages in the farnesyl chain [23-26].

\section{Experimental Section}

\subsection{General Experimental Procedure}

Specific rotations were measured by an $\mathrm{SGW}^{\circledR}-1$ automatic polarimeter (Shanghai Jing Ke Industrial Co., Ltd., Shanghai, China). Ultraviolet (UV) spectra were measured on a UV-2600 spectrometer. ECD spectra were measured on an Aviv Model 420SF spectropolarimeter (Aviv Biomedical Inc., Lakewood, CO, USA). The NMR spectra were recorded on a Bruker Avance III HD-400 and HD 600 NMR spectrometers (Bruker, Fällanden, Switzerland). HRESIMS spectra were obtained on an AB Sciex Triple TOF 4600 spectrometer (AB Sciex Pte. Ltd., Redwood City, CA, USA) fitted with an electrospray ionization (ESI) source. Semi-preparative high-performance liquid chromatography (HPLC) was undertaken on a Shimadzu LC-6AD pump (Shimadzu Co., Kyoto, Japan) using a UV detector, and a YMC-Pack ODS-A HPLC column (semipreparative, $250 \times 10 \mathrm{~mm}$, S-5 $\mu \mathrm{m}, 12 \mathrm{~nm}$, YMC Co., Ltd, Kyoto, Japan) was used for separation.

\subsection{Fungal Strain and Identification}

Fungus Penicillium sp. YPGA11 [13] (originally named YPCMAC1) was isolated from the deep-sea water at a depth of $4500 \mathrm{~m}$ in the Yap Trench $\left(138^{\circ} 0.74^{\prime} \mathrm{E}, 8^{\circ} 0.36^{\prime} \mathrm{N}\right.$, West Pacific Ocean). The strain was identified as Penicillium sp. based on microscopic examination and by internal transcribed spacer (ITS) sequencing. The ITS sequence has been deposited in GenBank (http:/ / www.ncbi.nlm.nih.gov) with accession number MG835908. The strain YPE1 (MCCC 3A00982) was deposited at the Marine Culture Collection of China.

\subsection{Fermentation}

The fermentation was carried out in 20 Fernbach flasks $(500 \mathrm{~mL})$, each containing $80 \mathrm{~g}$ of rice. Distilled $\mathrm{H}_{2} \mathrm{O}(100 \mathrm{~mL})$ was added to each flask, and the contents were soaked overnight before autoclaving at $15 \mathrm{psi}$ for $30 \mathrm{~min}$. After cooling to room temperature, each flask was inoculated with $5.0 \mathrm{~mL}$ of the spore inoculum and incubated at $30^{\circ} \mathrm{C}$ for 30 days. 


\subsection{Extraction and Isolation}

The fermented material was extracted with EtOAc $(3 \times 2000 \mathrm{~mL})$. After evaporation under vacuum, the EtOAc extract (2.0 g) was subjected to ODS silica gel column chromatography (CC) eluting with $\mathrm{MeOH} / \mathrm{H}_{2} \mathrm{O}(20: 80 \rightarrow 100: 0)$ to obtain seven fractions (F1-F7). F5 (159 mg) was further chromatographed over C-18 silica gel CC eluted with $\mathrm{MeOH} / \mathrm{H}_{2} \mathrm{O}(50: 50 \rightarrow 70: 30)$ to to afford four subfractions $\left(\mathrm{SF}_{\mathrm{a}}-\mathrm{SF}_{\mathrm{d}}\right) . \mathrm{SF}_{\mathrm{a}}(41 \mathrm{mg})$ was purified by HPLC on a semipreparative YMC-pack ODS-A column using $\mathrm{MeOH} / \mathrm{H}_{2} \mathrm{O}(65: 35,2 \mathrm{~mL} / \mathrm{min})$ as a mobile phase to obtain $3\left(4.2 \mathrm{mg}, \mathrm{t}_{R} 17.3 \mathrm{~min}\right)$ and $2\left(2.1 \mathrm{mg}, \mathrm{t}_{R} 18.2 \mathrm{~min}\right) . \mathrm{SF}_{\mathrm{b}}(28 \mathrm{mg})$ was separated by HPLC using the YMC-pack ODS-A column eluted by $\mathrm{MeOH} / \mathrm{H}_{2} \mathrm{O}(65: 35,2 \mathrm{~mL} / \mathrm{min})$ to afford $5\left(3.0 \mathrm{mg}, \mathrm{t}_{R} 39.5 \mathrm{~min}\right)$ and $\mathbf{1}\left(1.7 \mathrm{mg}, \mathrm{t}_{R} 40.9 \mathrm{~min}\right)$. $\mathrm{SF}_{\mathrm{d}}(31 \mathrm{mg})$ was subjected to HPLC on the YMC-pack ODS-A column with a mobile phase of $\mathrm{MeCN} / \mathrm{H}_{2} \mathrm{O}(60: 40,2 \mathrm{~mL} / \mathrm{min})$ to yield $4\left(1.6 \mathrm{mg}\right.$, $\left.\mathrm{t}_{R} 28.5 \mathrm{~min}\right)$.

Peniginsengin B (1): colorless oil; $[\alpha] 25 D+136(c 0.1, \mathrm{MeOH}) ; \mathrm{UV}(\mathrm{MeOH}) \lambda_{\max } 241$ (3.97) nm; $\operatorname{ECD}\left(c 6.0 \times 10^{-4} \mathrm{M}, \mathrm{MeOH}\right) \lambda_{\max }(\Delta \varepsilon) 226(+1.42), 241(-2.50)$; negative ESIMS $m / z 333.47\left[\mathrm{M}-\mathrm{H}^{-}{ }^{-}\right.$, $667.51[2 \mathrm{M}-\mathrm{H}]^{-} ;{ }^{1} \mathrm{H}$ and ${ }^{13} \mathrm{C}$ NMR data, see Table 1 ; HRESIMS $m / z 333.1703$ [M $\left.-\mathrm{H}\right]^{-}$(calcd. for $\mathrm{C}_{19} \mathrm{H}_{25} \mathrm{O}_{5}{ }^{-}$, 333.1707).

Peniginsengin C (2): colorless oil; [ $\alpha] 25 D+165$ (c 0.1, MeOH); UV (MeOH) $\lambda_{\max } 232$ (3.27) nm; $\left(c 8.9 \times 10^{-4} \mathrm{M}, \mathrm{MeOH}\right) \lambda_{\max }(\Delta \varepsilon) 210(+5.25), 245(-4.37) ;{ }^{1} \mathrm{H}$ and ${ }^{13} \mathrm{C}$ NMR data, see Table 1; negative ESIMS $m / z$; negative ESIMS $m / z 335.44[\mathrm{M}-\mathrm{H}]^{-}, 671.51[2 \mathrm{M}-\mathrm{H}]^{-}$; HRESIMS $m / z$ $335.1862[\mathrm{M}-\mathrm{H}]^{-}$(calcd. for $\left.\mathrm{C}_{19} \mathrm{H}_{27} \mathrm{O}_{5}{ }^{-}, 335.1864\right)$.

Peniginsengin D (3): colorless oil; $[\alpha] 25 D+88(c 0.1, \mathrm{MeOH}) ;{ }^{1} \mathrm{H}$ and ${ }^{13} \mathrm{C}$ NMR data, see Table 2; negative ESIMS $m / z 335.71[\mathrm{M}-\mathrm{H}]^{-}, 671.53[2 \mathrm{M}-\mathrm{H}]^{-}$; HRESIMS $m / z 335.1868[\mathrm{M}-\mathrm{H}]^{-}$(calcd. $^{-}$ for $\mathrm{C}_{19} \mathrm{H}_{27} \mathrm{O}_{5}{ }^{-}$, 335.1864).

Peniginsengin E (4): colorless oil; $[\alpha] 25 D+119$ ( $0.1, \mathrm{MeOH})$; UV (MeOH) $\lambda_{\max } 240$ (3.27) nm; $\operatorname{ECD}\left(c 4.0 \times 10^{-4} \mathrm{M}, \mathrm{MeOH}\right) \lambda_{\max }(\Delta \varepsilon) 227(-4.11), 331$ (+2.90); positive ESIMS $m / z 399.31[\mathrm{M}+\mathrm{Na}]^{+}$; ${ }^{1} \mathrm{H}$ and ${ }^{13} \mathrm{C}$ NMR data, see Table 2; negative ESIMS $m / z$ 751.58 $[2 \mathrm{M}-\mathrm{H}]^{-}$; HRESIMS $\mathrm{m} / \mathrm{z}$ $375.1813[\mathrm{M}-\mathrm{H}]^{-}$(calcd. for $\mathrm{C}_{21} \mathrm{H}_{27} \mathrm{O}_{6}{ }^{-}, 375.1813$ ).

\subsection{Computation Section}

In general, conformational analyses were carried out via random searching in the Sybyl-X 2.0 using the MMFF94S force field with an energy cutoff of $2.5 \mathrm{kcal} / \mathrm{mol}$. Subsequently, the conformers were re-optimized using density functional theory (DFT) at the B3LYP/6-31+G(d) level in $\mathrm{MeOH}$ using the polarizable conductor calculation model by the GAUSSIAN 09 program. The energies, oscillator strengths, and rotational strengths (velocity) of the first 30 electronic excitations were calculated using the TDDFT methodology at the B3LYP/6-311++G(d,p) level in MeOH. The ECD spectra were simulated by the overlapping Gaussian function (half the bandwidth at 1/e peak height, $\sigma=0.20,0.20,0.25$ for 1, 2, and 5, respectively). By comparing the experiment spectra with the calculated ECD spectra, the absolute configuration of $\mathbf{1}, \mathbf{2}, \mathbf{4}$, and $\mathbf{5}$ was resolved.

\subsection{Antibacterial Assay}

The strains used in antimicrobial tests were obtained from ATCC: S. aureus ATCC 43300 (methicillin-resistant S. aureus, MRSA) and S. aureus ATCC 29213 (methicillin-sensitive S. aureus, MSSA). The minimum inhibitory concentrations (MIC) were determined using the broth micro-dilution method according to the Clinical and Laboratory Standards Institute (CLSI) 2015 guideline. The commercial antimicrobial agents Penicillin and Vancomycin were used as positive controls. After 16-20 h incubation at $37^{\circ} \mathrm{C}$, MIC values were defined as the lowest concentrations of antibiotics with no visible growth of bacteria. MIC values of more than $128 \mu \mathrm{g} / \mathrm{mL}$ were considered as no activity [27]. 


\section{Conclusions}

In conclusion, four new farnesylcyclohexenones (1-4) and a known analog (5) were isolated from a fraction of the EtOAc extract of the deep sea-derived fungus Penicillium sp. YPGA11. Peniginsengin A-E (1-5), characterized by a highly oxygenated 1-methylcyclohexene unit and a rare (4E,8E)-4,8-dimethyldeca-4,8-dienoic acid side chain, are rarely found in nature. The absolute configurations of peniginsengins were resolved for the first time by ECD calculations in the current study. Compounds 2-4 exhibited moderate antibacterial activity against Staphylococcus aureus. Our study enriches the structure diversity of deep sea-derived natural products.

Supplementary Materials: The following are available online at http:/ / www.mdpi.com/1660-3397/16/10/358/s1, Figures S1-S28: HRESIMS, ${ }^{1} \mathrm{H},{ }^{13} \mathrm{C}$ NMR, HSQC, HMBC, NOESY, and ${ }^{1} \mathrm{H}-{ }^{1} \mathrm{H}$ COSY spectra of the new compounds 1-4, Table S1: NMR data of 3 in DMSO- $d_{6}$.

Author Contributions: Z.C., L. L. and S.L. isolated the compounds; W.X. and Z.L. isolated and identified the fungus, and conducted the solid fermentation of the fungus; J.Z. and Y.C. tested the antibacterial effects; Q.L., W.Y. and Z.C. designed the study, elucidated the structures, and edited the manuscript.

Funding: This work was supported by the grants from National Key R\&D Program of China (2017YFD0600702-2), China Postdoctoral Science Foundation (2018M630815), and National Standardization of Traditional Chinese Medicine of China (ZYBZH-Y-HEN-19).

Acknowledgments: The authors thank Wei Cheng in Peking University for ECD calculations and Jianxun Kang in Zhengzhou University for NMR measurements.

Conflicts of Interest: The authors declare no conflict of interest.

\section{References}

1. Vansteelandt, M.; Roullier, C.; Blanchet, E.; Guitton, Y.; Pouchus, Y.; Ruiz, N.; Grovel, O. Impact of Marine-Derived Penicillium Species in the Discovery of New Potential Antitumor Drugs. In Outstanding Marine Molecules; Barre, S.L., Kornprobst, J.M., Eds.; Wiley Blackwell Publishing: Malden, MA, USA, 2014; pp. 45-84.

2. Kong, F.D.; Ma, Q.Y.; Huang, S.Z.; Wang, P.; Wang, J.F.; Zhou, L.M.; Yuan, J.Z.; Dai, H.F.; Zhao, Y.X. Chrodrimanins K-N and related meroterpenoids from the fungus Penicillium sp. SCS-KFD09 isolated from a marine worm, Sipunculus nudus. J. Nat. Prod. 2017, 80, 1039-1047. [CrossRef] [PubMed]

3. Zhu, M.; Zhang, X.; Feng, H.; Dai, J.; Li, J.; Che, Q.; Gu, Q.; Zhu, T.; Li, D. Penicisulfuranols A-F, alkaloids from the mangrove endophytic fungus Penicillium janthinellum HDN13-309. J. Nat. Prod. 2017, 80, 71-75. [CrossRef] [PubMed]

4. Li, H.L.; Xu, R.; Li, X.M.; Yang, S.Q.; Meng, L.H.; Wang, B.G. Simpterpenoid A, a meroterpenoid with a highly functionalized cyclohexadiene moiety featuring gem-propane-1,2-dione and methylformate groups, from the mangrove-derived Penicillium simplicissimum MA-332. Org. Lett. 2018, 20, 1465-1468. [CrossRef] [PubMed]

5. Blunt, J.W.; Carroll, A.R.; Copp, B.R.; Davis, R.A.; Keyzers, R.A.; Prinsep, M.R. Marine natural products. Nat. Prod. Rep. 2018, 35, 8-53. [CrossRef] [PubMed]

6. Guo, W.; Zhang, Z.; Zhu, T.; Gu, Q.; Li, D. Penicyclones A-E, antibacterial polyketides from the deep-sea-derived fungus Penicillium sp. F23-2. J. Nat. Prod. 2015, 78, 2699-2703. [CrossRef] [PubMed]

7. Gao, S.S.; Li, X.M.; Du, F.Y.; Li, C.S.; Proksch, P.; Wang, B.G. Secondary metabolites from a marine-derived endophytic fungus Penicillium chrysogenum QEN-24S. Mar. Drugs 2011, 9, 59-70. [CrossRef] [PubMed]

8. Hu, X.Y.; Meng, L.H.; Li, X.; Yang, S.Q.; Li, X.M.; Wang, B.G. Three new indole diterpenoids from the sea-anemone-derived fungus Penicillium sp. AS-79. Mar. Drugs 2017, 15, 137. [CrossRef] [PubMed]

9. Nicoletti, R.; Trincone, A. Bioactive compounds produced by strains of Penicillium and Talaromyces of marine origin. Mar. Drugs 2016, 14, 37. [CrossRef] [PubMed]

10. Cheng, Z.; Zhao, J.; Liu, D.; Proksch, P.; Zhao, Z.; Lin, W. Eremophilane-type sesquiterpenoids from an Acremonium sp. fungus isolated from deep-sea sediments. J. Nat. Prod. 2016, 79, 1035-1047. [CrossRef] [PubMed] 
11. Cheng, Z.; Lou, L.; Liu, D.; Li, X.; Proksch, P.; Yin, S.; Lin, W. Versiquinazolines A-K, fumiquinazoline-type alkaloids from the gorgonian-derived fungus Aspergillus versicolor LZD-14-1. J. Nat. Prod. 2016, 79, 2941-2952. [CrossRef] [PubMed]

12. Chen, R.; Cheng, Z.; Huang, J.; Liu, D.; Wu, C.; Guo, P.; Lin, W. Versicotides D-F, new cyclopeptides with lipid-lowering activities. RSC Adv. 2017, 7, 49235-49243. [CrossRef]

13. Liu, L.; Xu, W.; Li, S.; Chen, M.; Cheng, Y.; Yuan, W.; Cheng, Z.; Li, Q. Penicindopene A, A new indole diterpene from the deep-sea fungus Penicillium sp. YPCMAC1. Nat. Prod. Res. 2018, in press..

14. Yang, Y.; Yang, F.; Zhao, L.; Duang, R.; Chen, G.; Li, X.; Li, Q.; Qin, S.; Ding, Z. A new polyoxygenated farnesylcyclohexenone from Fungus Penicillium sp. Nat. Prod. Res. 2016, 30, 65-68. [CrossRef] [PubMed]

15. Zhuang, P.; Tang, X.X.; Yi, Z.W.; Qiu, Y.K.; Wu, Z. Two new compounds from marine-derived fungus Penicillium sp. F11. J. Asian Nat. Prod. Res. 2012, 14, 197-203. [CrossRef] [PubMed]

16. Liu, D.; Yang, A.; Wu, C.; Guo, P.; Proksch, P.; Lin, W. Lipid-lowering effects of farnesylquinone and related analogues from the marine-derived Streptomyces nitrosporeus. Bioorg. Med. Chem. Lett. 2014, 24, 5288-5293. [CrossRef] [PubMed]

17. Zheng, C.J.; Shao, C.L.; Chen, M.; Niu, Z.G.; Zhao, D.L.; Wang, C.Y. Merosesquiterpenoids and ten-membered macrolides from a soft coral-derived lophiostoma sp. Fungus. Chem. Biodivers. 2015, 12, 1407-1414. [CrossRef] [PubMed]

18. Li, J.Y.; Harper, J.K.; Grant, D.M.; Tombe, B.O.; Bashyal, B.; Hess, W.M.; Strobel, G.A. Ambuic acid, a highly functionalized cyclohexenone with antifungal activity from Pestalotiopsis spp. and Monochaetia sp. Phytochemistry 2001, 56, 463-468. [CrossRef]

19. Li, C.S.; Yang, B.J.; Turkson, J.; Cao, S. Anti-proliferative ambuic acid derivatives from Hawaiian endophytic fungus Pestalotiopsis sp. FT172. Phytochemistry 2017, 140, 77-82. [CrossRef] [PubMed]

20. Qi, Q.Y.; Li, E.W.; Han, J.J.; Pei, Y.F.; Ma, K.; Bao, L.; Huang, Y.; Zhao, F.; Liu, H.W. New ambuic acid derivatives from the solid culture of Pestalotiopsis neglecta and their nitric oxide inhibitory activity. Sci. Rep. 2015, 5, 9958. [CrossRef] [PubMed]

21. Li, J.; Xie, J.; Yu, F.X.; Chen, Y.H.; Zhao, P.J. Pestalotic acids A-I, antibacterial ambuic acid analogues, from a mycoparasite (Pestalotipsis sp. cr014) of Cronartium ribicola. Arch. Pharmacal Res. 2016, 19, 1-9. [CrossRef] [PubMed]

22. Ding, G.; Li, Y.; Fu, S.; Liu, S.; Wei, J.; Che, Y. Ambuic acid and torreyanic acid derivatives from the endolichenic fungus Pestalotiopsis sp. J. Nat. Prod. 2009, 72, 182-186. [CrossRef] [PubMed]

23. Song, T.Y.; Xu, Z.F.; Chen, Y.H.; Ding, Q.Y.; Sun, Y.R.; Miao, Y.; Zhang, K.Q.; Niu, X.M. Potent nematicidal activity and new hybrid metabolite production by disruption of a Cytochrome P450 gene involved in the biosynthesis of morphological regulatory arthrosporols in nematode-trapping fungus Arthrobotrys oligospora. J. Agric. Food Chem. 2017, 65, 4111-4120. [CrossRef] [PubMed]

24. Bugni, T.S.; Abbanat, D.; Bernan, V.S.; Maiese, W.M.; Greenstein, M.; Van Wagoner, R.M.; Ireland, C.M. Yanuthones: Novel metabolites from a marine isolate of Aspergillus niger. J. Org. Chem. 2000, 65, 7195-7200. [CrossRef] [PubMed]

25. Petersen, L.M.; Holm, D.K.; Knudsen, P.B.; Nielsen, K.F.; Gotfredsen, C.H.; Mortensen, U.H.; Larsen, T.O. Characterization of four new antifungal yanuthones from Aspergillus niger. J. Antibiot. 2014, 68, 201-205. [CrossRef] [PubMed]

26. Mehta, G.; Pan, S.C. First total synthesis of yanuthones: Novel farnesylated epoxycyclohexenoid marine natural products. Tetrahedron Lett. 2005, 46, 5219-5223. [CrossRef]

27. Cheng, Z.B.; Xiao, H.; Fan, C.Q.; Lu, Y.N.; Zhang, G.; Yin, S. Bioactive polyhydroxylated sterols from the marine sponge Haliclona crassiloba. Steroids 2013, 78, 1353-1358. [CrossRef] [PubMed]

(C) 2018 by the authors. Licensee MDPI, Basel, Switzerland. This article is an open access article distributed under the terms and conditions of the Creative Commons Attribution (CC BY) license (http:/ / creativecommons.org/licenses/by/4.0/). 